\title{
Anaerobic treatment of p-acetamidobenzene sulfonyl chloride (p-ASC)-containing wastewater in the presence or absence of ethanol in a UASB reactor
}

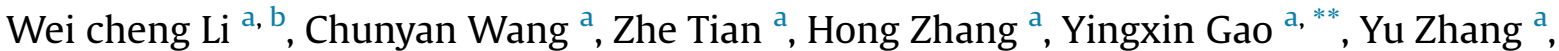 \\ Min Yang ${ }^{a}$, Yu-You Li ${ }^{b},{ }^{*}$, Osamu Nishimura ${ }^{b}$ \\ a State Key Laboratory of Environmental Aquatic Chemistry, Research Center for Eco-Environmental Sciences, Chinese Academy of Science, Post Office Box \\ 2871, Beijing 100085, China \\ ${ }^{\mathrm{b}}$ Department of Civil and Environmental Engineering, Graduate School of Engineering, Tohoku University, 6-6-06 Aza-Aoba, Aramaki, Aoba-ku, Sendai, \\ Miyagi 980-8579, Japan
}

\section{A R T I C L E I N F O}

\section{Article history:}

Received 12 March 2014

Received in revised form

7 August 2014

Accepted 9 September 2014

Available online 31 December 2014

\section{Keywords:}

p-acetamidobenzene sulfonyl chloride

Anaerobic treatment

Aromatic sulfonates

Industrial wastewater

Microbial community structure

\begin{abstract}
A B S T R A C T
A lab-scale UASB reactor was operated for the treatment of p-acetamidobenzene sulfonyl chloride (pASC)-containing wastewater with and without ethanol for 210 days. The influence of the organic loading rate on the performance of reactor by step-decreasing HRT reduction/step-increasing the concentration of p-ASC was evaluated. Almost complete degradation of $50 \mathrm{mg} / \mathrm{l} \mathrm{p}$-ASC and COD removal efficiency (79.5\%) was noticed with a COD removal of $79.5 \%$ at HRT of 0.5 day or longer and an applied p-ASC loading rate below $120 \mathrm{mg} / \mathrm{l} / \mathrm{day}$. No inhibition to the performance of this reactor was observed even at a p-ASC concentration up to $1000 \mathrm{mg} / \mathrm{l}$. Of interest that despite the absence of sulfate in the feed, a certain quantity of sulfate and sulfide was simultaneously generated in the effluent. The trial result in the absence of ethanol demonstrated that p-ASC could be used as the sole source of carbon and energy. Clone libraries for the archaeal and bacterial communities were constructed for a biomass sample taken on day 190. The majority of bacterial clones were represented by Proteobacteria, followed by Thermotogae, Bacteroidetes and Firmicutes. Bacterial groups within the phyla Clostridia might be responsible for the desulfonation of p-ASC.
\end{abstract}

\section{Introduction}

Aromatic sulfonates include a wide range of chemicals and are extensively applied as important industrial chemicals, especially in the dye and pharmaceutical industries. The presence of a sulfonated group makes these compounds highly water-soluble (Tan et al., 2005), which results in the generation of large volumes of high strength industrial waste streams (Zerbinati et al., 1997). The dominant approach to remove organic matter from high strength industrial wastewater is anaerobic digestion due to the low energy input required, the sludge yield and the production of biogas as clean fuel. Two sulfonated azo dyes (Acid Orange 7 and Direct Red

* Corresponding author. Tel.: +81 22 7957464; fax: +81 3737957465 .

** Corresponding author. Tel.: +86 10 62943475; fax: +86 1062923541.

E-mail addresses: gyx@rcees.ac.cn (Y. Gao), yyli@epl1.civil.tohoku.ac.jp (Y.-Y. Li).
254) have been observed to be effectively degraded in a methanogenic UASB reactor (Brás et al., 2005). However, it has taken time to understand the anaerobic treatability of linear alkylbenzene sulfonate (LAS), which historically had been considered to severely impede methane production and persist during anaerobic treatment. It was reported by Prats et al. (1997) that LAS can be anaerobically degraded in the presence of various electron donors. Until now, the treatability of the aromatic sulfonates-containing wastewater under anaerobic conditions could only be elucidated through experimental approaches.

p-Acetamidobenzene sulfonyl chloride ( $\mathrm{p}$-ASC), is a derivative of sulfonated aromatic amines as shown in Fig. 1. It has been applied as an intermediate in the synthesis of p-aminobenzene sulfonamide (sulfanilamide, SN), one of the most frequently used sulfonamide type antibacterial medicines (Tan et al., 2011). Since the synthesis operations in pharmaceutical manufacturing industries usually generate larger volumes of wastewater (Chelliapan et al., 
<smiles>CC(=O)Nc1ccc(S(=O)(=O)Cl)cc1</smiles>

Fig. 1. Chemical structure of p-acetamidobenzene sulfonyl chloride (p-ASC).

2011), it is vital that wastewater containing p-ASC and other organic compounds is treated both effectively and economically during the SN production process. The reduction of azo dyes results in the formation of aromatic amines that mostly cannot be metabolized anaerobically. The exception of a few examples bearing hydroxyl and carboxyl groups can be fully degraded under methanogenic conditions (Razo-Flores et al., 1996). The conclusion can be also confirmed in an earlier study, which show that sulfonated aromatic amines are not readily degraded (Lange et al., 1995b). Tan et al. (2005) investigated the biodegradation of ten sulfonated aromatic amines including 2,4-diaminobenzenesulfonic acid, 1-aminonaphthalene-4-sulfonic acid, etc. in both aerobic and anaerobic conditions. None of the sulfonated aromatic amines tested were degraded anaerobically, while aerobic degradation was only observed with the inoculum sources that were historically polluted with sulfonated aromatic amines. To the best of our knowledge, almost no literature has been published so far on anaerobic degradation of p-ASC. In this study, a USAB reactor was established to treat $\mathrm{p}$-ASC-containing wastewater under different conditions for a period of 210 days. The performance of the reactor was evaluated by following the changes of the p-ASC, COD and volatile organic acid concentrations in the effluent and the methane production rate. At the same time, clone libraries for the archaeal and bacterial communities were constructed for a biomass sample taken on day 190 to analyze the microbial population possibly involved in p-ASC degradation. The study could provide useful information for the treatment of wastewater containing pASC or similar compounds.

\section{Materials and methods}

\section{Experiment set-up}

The UASB reactor was made of a plexiglass cylinder with an internal diameter of $100 \mathrm{~mm}$ and a working volume of $6 \mathrm{l}$, as shown in Fig. 2. The reactor was water-jacketed to keep a constant temperature at $37 \pm 2{ }^{\circ} \mathrm{C}$. The produced gas was sequentially absorbed by a $3 \mathrm{~N} \mathrm{NaOH}$ solution and soda lime pellets to remove $\mathrm{H}_{2} \mathrm{~S}$ and $\mathrm{CO}_{2}$, respectively, and then recorded by a wet gas meter.

\section{Reactor operation}

The mesophilic UASB reactor was inoculated with 31 granule sludge partly from a UASB reactor treating pharmaceutical wastewater containing p-ASC for one year and partly from a full-scale UASB reactor treating food manufacturing wastewater. The initial sludge concentration was $46.5 \mathrm{~g}$ VSS/l. Synthetic wastewater consisting varying concentrations of p-ASC with and without ethanol was prepared and fed into the reactor at different stages over a period of 200 days, as detailed in Table 1. The initial OLR (organic loading rate) was $1.0 \mathrm{~g} \mathrm{COD} / \mathrm{l} / \mathrm{day}$, corresponding to an initial hydraulic retention time (HRT) of 3.5 days. Then the OLR was elevated to around $24.0 \mathrm{~g} \mathrm{COD/1/day} \mathrm{by} \mathrm{shortening} \mathrm{HRT} \mathrm{stepwise} \mathrm{in} \mathrm{Stage} \mathrm{I.}$ Thereafter, in Period II, the OLR was decreased backward to $7.0 \mathrm{~g} \mathrm{COD} / \mathrm{l} / \mathrm{day}$ (HRT 0.5 day) to investigate the recovery ability of the reactor. The impacts of p-ASC to anaerobic treatment were evaluated by increasing p-ASC concentration in Stage III. Finally the reactor was operated without ethanol in Stage IV.

\section{Analytical methods}

The chemical oxygen demand (COD), $\mathrm{pH}$, soluble sulfide, volatile fatty acids (VFA) and volatile suspended solids (VSS) were determined according to the standard analytical procedures published by the APHA (1998). Prior to COD measurement, the solution was aerated to oxidize $S^{2-}$ to $S$ deposit in order to prevent the interference by sulfide (Sun and Guan, 2009). The sulfide concentration in the effluent was measured using iodometric method, while the

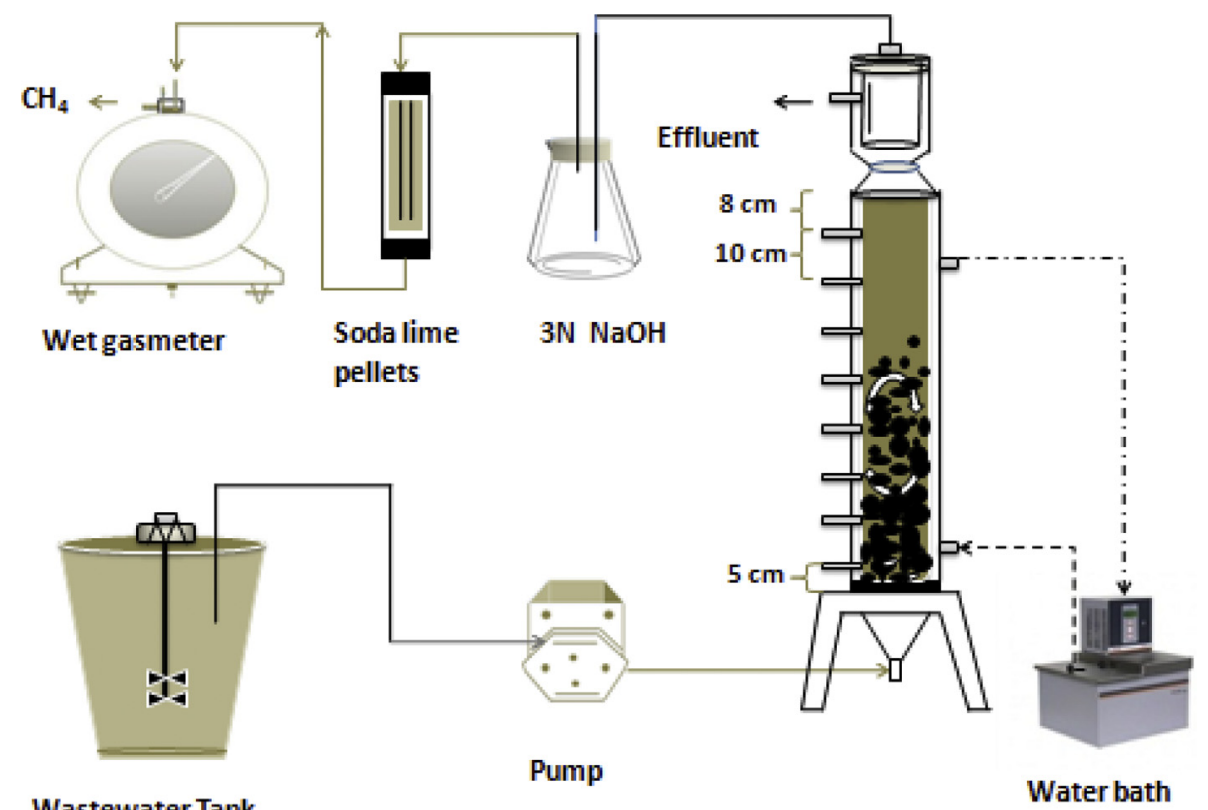

Fig. 2. Schematic diagram of the UASB set-up. 
Table 1

Characterization of the different period of UASB reactors operation.

\begin{tabular}{|c|c|c|c|c|c|c|c|}
\hline Period & Days & $\begin{array}{l}\text { COD } \\
(\mathrm{mg} / \mathrm{l})\end{array}$ & $\begin{array}{l}\text { p-ASC } \\
(\mathrm{mg} / \mathrm{l})\end{array}$ & $\begin{array}{l}\text { p-ASC loading } \\
\text { rate }(\mathrm{mg} / \mathrm{l} / \mathrm{day})\end{array}$ & $\begin{array}{l}\text { Ethanol } \\
(\mathrm{mg} / \mathrm{l})\end{array}$ & $\begin{array}{l}\text { OLR } \\
\text { (g COD/l/day) }\end{array}$ & $\begin{array}{l}\text { HRT } \\
\text { (day) }\end{array}$ \\
\hline \multirow[t]{8}{*}{ I } & $1-15$ & 3400 & 50 & 14.2 & 1600 & 1.0 & 3.50 \\
\hline & $16-25$ & & 50 & 28.4 & 1600 & 2.0 & 1.76 \\
\hline & $26-35$ & & 50 & 42.6 & 1600 & 3.0 & 1.20 \\
\hline & $36-50$ & & 50 & 57.2 & 1600 & 4.0 & 0.88 \\
\hline & $51-65$ & & 50 & 99.4 & 1600 & 7.0 & 0.50 \\
\hline & $66-80$ & & 50 & 170.4 & 1600 & 12.0 & 0.30 \\
\hline & $81-95$ & & 50 & 224.3 & 1600 & 16.0 & 0.22 \\
\hline & $96-110$ & & 50 & 340.2 & 1600 & 24.0 & 0.15 \\
\hline II & $111-130$ & 3400 & 50 & 99.4 & 1600 & 7.0 & 0.5 \\
\hline \multirow[t]{3}{*}{ III } & $131-150$ & 3900 & 400 & 795.2 & 1600 & 7.9 & 0.50 \\
\hline & $151-170$ & 4600 & 1000 & 1988 & 1600 & 9.15 & 0.50 \\
\hline & $171-190$ & 3900 & 400 & 795.2 & 1600 & 7.9 & 0.50 \\
\hline IV & $191-210$ & 550 & 400 & 795.2 & 0 & 1.1 & 0.50 \\
\hline
\end{tabular}

sulfate concentration was determined on an ion exchange chromatography (ICS-2100, DIONEX). The biogas composition was monitored on a gas chromatography (Agilent 7890A) equipped with a thermal conductivity detector (TCD). The concentrations of short-chain organic acids and ethanol were determined on a gas chromatography (GC 2010, SHIMADZU) equipped with an HP-FFAP capillary column and a flame ionization detector using helium as the carrier gas.

The concentration of $\mathrm{p}$-ASC was determined on a highperformance liquid chromatography (HPLC) (Breeze 1525, Waters) equipped with an HPLC column (250_4.6 mm Zorbax ExtendC18, Agilent) and 2487 Dual $\lambda$ Absorbance Detector (Waters). The column temperature was maintained at $25{ }^{\circ} \mathrm{C}$. The mobile phase consisting of $85 \%$ of solvent A (water) and $15 \%$ of solvent B $(0.05 \mathrm{M}$ ammonium acetate in water) was passed through the column with a flow rate of $1 \mathrm{ml} / \mathrm{min}$. Calibration curves was obtained at a detection wavelength of $245 \mathrm{~nm}$ using a series of standard solutions over the concentration range from 1 to $20 \mathrm{mg} / \mathrm{l}$. Calibration curve was linear over the concentration ranges tested with correlation coefficient of 0.999 . The corresponding recovery was $98.9 \%$ and the detection limit was approximately $30 \mu \mathrm{g} / \mathrm{l}$.

\section{Cloning analysis of $16 S$ rRNA gene}

A biomass sample was collected from the reactor on day 190 . Cells were harvested by the centrifugation of the sample at $20,000 \times g$ for $10 \mathrm{~min}$, and then used for DNA extraction from the sample with a FastPrep DNA Extraction Kit for Soil in a FastPrep FP120 Cell Disrupter (Qbiogene, USA). 16S rRNA genes were amplified with the universal primers 27F ( $5^{\prime}$-AGAGTTTGATCATGGC- $\left.3^{\prime}\right)$ and 1492R ( $5^{\prime}$-TACCTTGTTACGACTT- $\left.3^{\prime}\right)$ for bacteria and 21F $\left(5^{\prime}-\right.$ TTCCGGTTGATCCYGC-CGGA-3') and 958R (5'-YCCGGCGTCCYGCCGGA-3') for archaea. Thermal cycling of PCR consisted of $60 \mathrm{~s}$ denaturing at $94^{\circ} \mathrm{C}, 30$ s of annealing at $55^{\circ} \mathrm{C}$, and extracting at $72{ }^{\circ} \mathrm{C}$ for 1.5 min with 30 cycles for bacteria. PCR of archaea was performed followed 23 cycles with $94{ }^{\circ} \mathrm{C}$ for $45 \mathrm{~s}, 55^{\circ} \mathrm{C}$ for $45 \mathrm{~s}, 72{ }^{\circ} \mathrm{C}$ for $60 \mathrm{~s}$. The PCR products were firstly purified and ligated into pMD18-T simple vectors (Takara, Japan). Recombinants were selected using X-Gal-IPTG LB indicator plates with $100 \mu \mathrm{g} / \mathrm{ml}$ ampicillin. White colonies were randomly picked and tested by PCR using vector of M13 primer. The successful ones were used for sequencing.

\section{Phylogenetic analysis}

Sequences were searched against the Ribosomal Database Project II (RDP II) release 9.49 and the GenBank database (http:// www.ncbi.nlm.nih.gov/blast/) by using the BLASTn program to determine the nearest matches. The sequences sharing $97 \%$ or great similarity were considered to represent the same operational taxonomic unit (OTU) using software DOTUR (Schloss and Handelsman, 2005).

\section{Results and discussion}

\section{Performance of UASB reactor under increasing OLR}

As shown in Fig. 3(a, b), the COD removal efficiency was kept in the range of $78.5-86.1 \%$ with the increase of OLR from 1.0 to $7.0 \mathrm{~g} \mathrm{COD} / 1 /$ day corresponding to an HRT decrease from 3.5 to 0.5 days. In parallel, the methane yield rate increased from 0.2 to $1.4 \mathrm{l} / \mathrm{l} /$ day (Fig. 3(c)). Meanwhile, almost no p-ASC was detected in the effluent (Fig. 4(c)), and the percentage of methane in the biogas was between $68 \%$ and $72 \%$ (Fig. 3(c)). Although sulfated aromatic amines have long been considered not readily biodegradable (Lange et al., 1995), the above results indicate that the UASB reactor was very efficient in treating the p-ASC-containing wastewater without acclimation of operation time. This could be attributed to the use of granule sludge from another UASB reactor previously treating pharmaceutical wastewater containing p-ASC where pASC-degrading microorganism was progressively acclimated with the extension of treatment process. Further increase of OLR to around $12.0 \mathrm{~g} \mathrm{COD} / \mathrm{l} /$ day led to a decrease in COD removal. However, even at an OLR as high as around $24.0 \mathrm{~g}$ COD/1/day and HRT of 0.15 day, a p-ASC removal efficiency of $93.4 \%$ was achieved (Fig. 4(c)) whereas the COD removal efficiency was only $52.5 \%$ (Fig. 3(a, b)). The reason for deterioration of the reactor performance under reducing HRT was that the contact time between wastewater and sludge was too short to allow sufficient biodegradation (Hazrati and Shayegan, 2011). The methane content in the biogas was still proximately 60\% (Fig. 3(c)). As shown in Fig. 3(d), acetate was the dominant VFA species, varying from approximately 250 to $670 \mathrm{mg} / \mathrm{l}$ over the whole period. Isopropanol, isobutyricacid, isovaleric acid and isopentanoic acid were detected in much lower concentrations (data not shown). At the same time, the effluent $\mathrm{pH}$ varied between 7.6 and 7.0 (Fig. 3(f)), suggesting that no significant inhibition took place in the reactor.

Variations of sulfate and sulfide in the effluent (Fig. 3(e)) with the change of HRT over time further supported the bioconversion of p-ASC. No sulfate was fed to this reactor during the whole process. Besides, the higher $\mathrm{pH}$ observed for effluent can be explained by the generation of alkalinity in the form of bicarbonate during the process of sulfate reduction by sulfate-reducing bacteria (SRB). It is speculated that the sulfonyl group linked to the aromatic group was cleaved and forms a sulfonic group, because sulfonyl group readily hydrolyzes in an aquatic environment (Su and Yang, 2002). Moreover, microorganism also involved the desulfonation process, which will be discussed later.

The above result demonstrated that anaerobic treatment was effective for p-ASC-containing wastewater. Even at an OLR as high as around $24.0 \mathrm{~g}$ COD/1/day and HRT of 0.15 day, most of p-ASC was removed. A summary of some of aromatic sulfonates (including sulfonated aromatic amines) removal in anaerobic conditions in some literature reviewed is presented in Table 2. Obviously, sulfonated aromatic amines are difficult to de degraded anaerobically. The pathway of p-ASC degradation in this anaerobic treatment isn't clear. According to the anaerobic degradation of aniline (structurally similar to p-ASC) by sulfate-reducing bacteria (Schnell and Schink, 1991), it can be speculated that the pathway of p-ASC degradation can mainly consist of five steps. The first step is the desulfonation process to cleave the sulfonyl group from the aromatic group, which is achieved by the combination of hydrolysis 

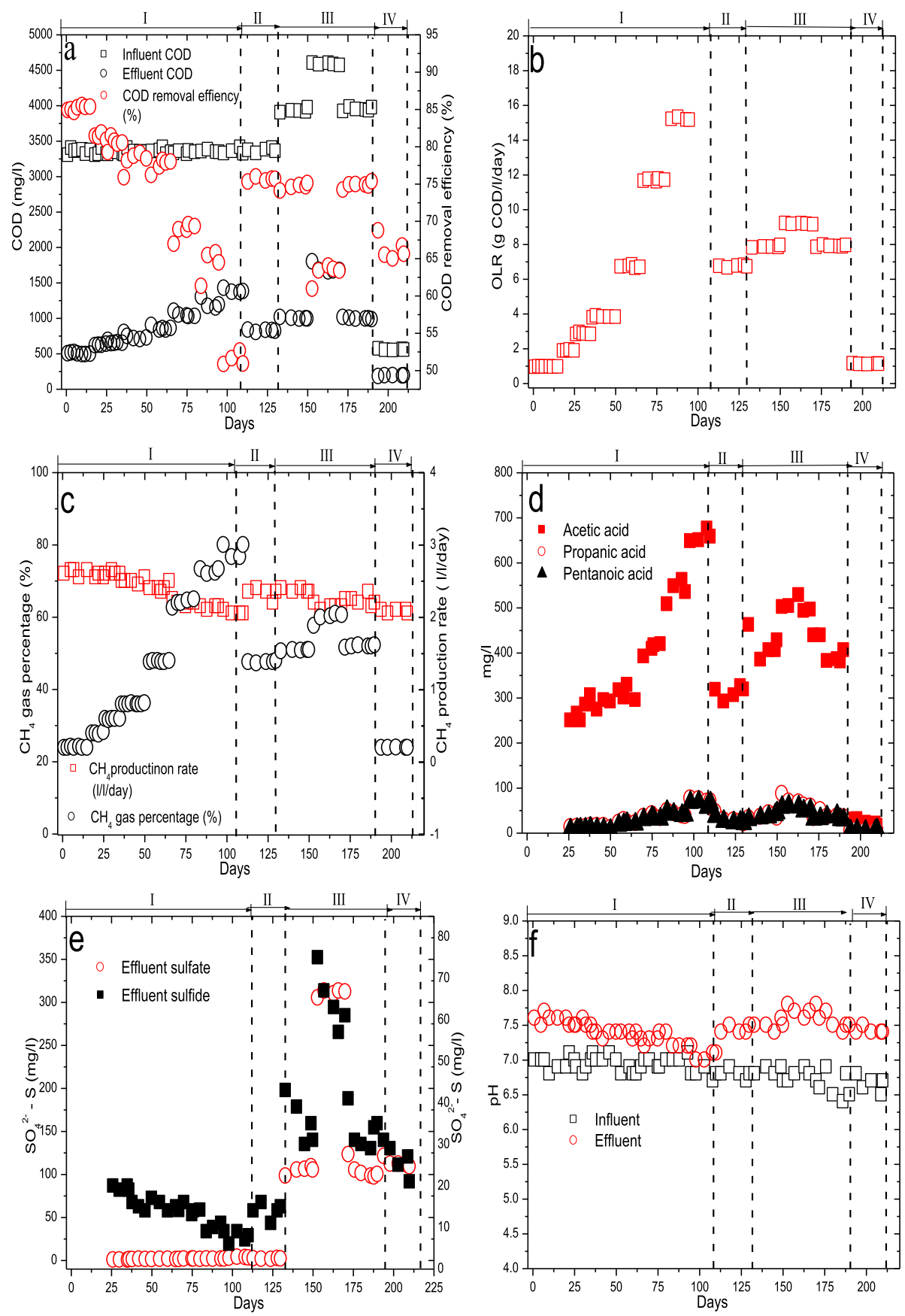

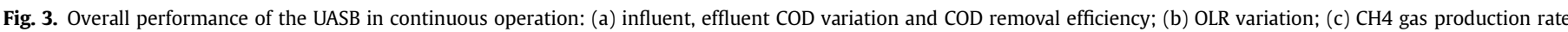
variation and CH4 gas percentage; (d) effluent VFA variation; (e) sulfate and dissolved sulfide in effluent; (f) pH changes.

process and degradation by microorganism (phyla Clostridia, mentioned later). Then, the second step seems to be carboxylation to 4-acetamidobenzoate, followed by activation of 4acetamidobenzoate to 4 -acetamidobenzoyl-CoA. The subsequent step will be reductive elimination of the acetamido group and enters the normal benzoate degradation pathway, finally leading to three acetyl-CoA. The pathway of p-ASC degradation under anaerobic condition need be further studied.

\section{Influence of $p$-ASC concentration on reactor performance}

To investigate the influence of p-ASC concentration on reactor performance, the reactor was firstly operated at an OLR of
$7.0 \mathrm{~g} \mathrm{COD} / 1 /$ day and HRT of 0.65 days from 131 day to 150 day (Stage II) to restore its performance (Stage II). As shown in Fig. 3(a), the COD removal efficiency quickly increased to $79.0 \%$ three days after the change of the operational conditions. The quick recovery further indicated that the microbial community was not seriously inhibited even under an OLR of around $24.0 \mathrm{~g}$ COD/1/day.

At the beginning of Period III (day 131), the reactor was fed with $400 \mathrm{mg} / \mathrm{l}$ of p-ASC and same ethanol concentration as Period II, providing a COD and p-ASC loading rate of around $3900 \mathrm{mg} / \mathrm{l}$ and $795.2 \mathrm{mg} / \mathrm{l} /$ day at an HRT of 0.5 days, respectively (Figs. 3(a, b), 4(a, b) and Table 1). A slight rise in the methane production rate to $1.55 \mathrm{l} / \mathrm{l} /$ day indicated that $\mathrm{p}$-ASC was not removed only by sorption process on granule. Actually, adsorption role was very limited for $\mathrm{p}$ - 

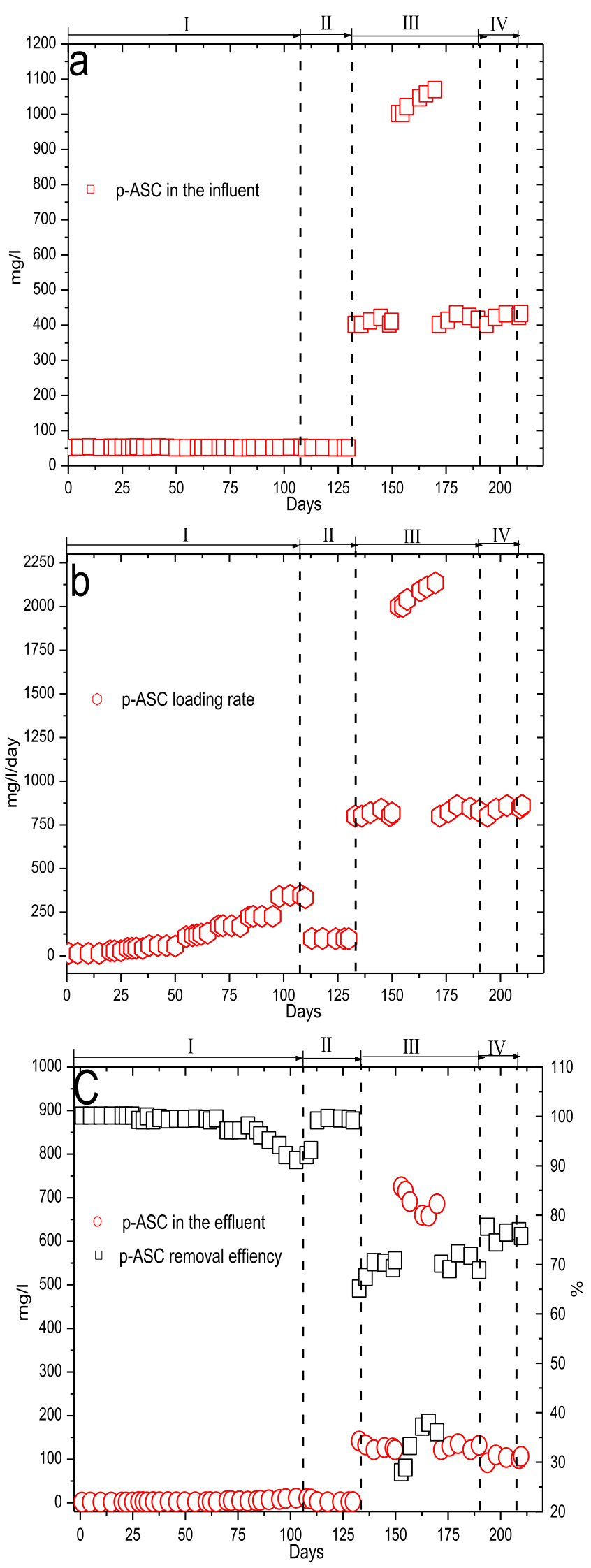

Fig. 4. (a) The concentration of p-ASC in the influent and p-ASC loading rate (mg/l/ day) in the continuous operation. (b) p-ASC loading rate in the continuous operation. (c) The concentration of p-ASC in the effluent and removal efficiency of p-ASC.
Table 2

Anaerobic systems treating some of aromatic sulfonates in literature.

\begin{tabular}{|c|c|c|c|c|c|}
\hline $\begin{array}{l}\text { Anaerobic } \\
\text { system }\end{array}$ & Compounds & Influent & $\begin{array}{l}\text { Removal } \\
\text { efficiency } \\
(\%)\end{array}$ & HRT & References \\
\hline UASB & Acid Orange $7^{\mathrm{a}}$ & $300 \mathrm{mg} / \mathrm{l}$ & 96 & $14 \mathrm{~h}$ & $\begin{array}{l}\text { Carvalho et al., } \\
2008\end{array}$ \\
\hline UASB & Acid Orange 7 & $300 \mathrm{mg} / \mathrm{l}$ & $>88$ & $24 \mathrm{~h}$ & Brás et al., 2005 \\
\hline UASB & Direct Red $254^{\mathrm{b}}$ & $300 \mathrm{mg} / \mathrm{l}$ & $>88$ & $24 \mathrm{~h}$ & Same as above \\
\hline UASB & LAS & $4-5 \mathrm{mg} / \mathrm{l}$ & $64-85$ & $24 \mathrm{~h}$ & Sanz et al., 2003 \\
\hline UASB & LAS & $14 \mathrm{mg} / \mathrm{l}$ & $35 \pm 12$ & $12 \mathrm{~h}$ & $\begin{array}{l}\text { Duarte et al., } \\
2010\end{array}$ \\
\hline UASB & LAS & $18.8 \pm 4.2 \mathrm{mg} / \mathrm{l}$ & $99 \pm 2$ & $18 \mathrm{~h}$ & $\begin{array}{l}\text { de Oliveira } \\
\text { et al., } 2010\end{array}$ \\
\hline Batch & $\mathrm{TS}^{\mathrm{c}}$ & $30 \mu \mathrm{M}$ & 100 & - & $\begin{array}{l}\text { Denger et al., } \\
1996\end{array}$ \\
\hline Batch & $\mathrm{SPO}^{\mathrm{d}}$ & $30 \mu \mathrm{M}$ & 100 & - & Same as Above \\
\hline Batch & 3-A-4-HBS & $100-200 \mathrm{mg} / \mathrm{l}$ & 0 & - & Tan et al., 2005 \\
\hline Batch & $1-A N-5-S^{f}$ & $100-200 \mathrm{mg} / \mathrm{l}$ & 0 & - & Same as Above \\
\hline Batch & $2-\mathrm{AN}-1,5-\mathrm{DS}^{\mathrm{g}}$ & $100-200 \mathrm{mg} / \mathrm{l}$ & 0 & - & Same as Above \\
\hline Batch & $3-A N-2,7-\mathrm{DS}^{\mathrm{h}}$ & $100-200 \mathrm{mg} / \mathrm{l}$ & 0 & - & Same as Above \\
\hline
\end{tabular}

Trial names not explained in the text: Acid Orange $7^{\mathrm{a}}$, sodium 4-[(2E)-2-(2oxonaphthalen-1-ylidene)hydrazinyl]benzenesulfonate; Direct Red 254 , (3E)-7amino-4-oxo-3-[[4-[(4-sulfophenyl)diazenyl]phenyl]hydrazinylidene]-naphtha-

lene-2-sulfonic acid; $\mathrm{TS}^{\mathrm{c}}$, 4-tolysulfonate; $\mathrm{SPO}^{\mathrm{d}}$, 1-(4-sulfophenyl)octane; 3-A-4$\mathrm{HBS}^{\mathrm{e}}$, 3-amino-4-hydroxybenzenesulfonic acid; 1-AN-5-S ${ }^{\mathrm{f}}$, 1-aminonaphthalene5-sulfonic acid; 2-AN-1,5-DS ${ }^{\mathrm{g}}$, 2-aminonaphthalene-1,5-disulfonic acid; 3-AN-2,7DS $^{\text {h }}, 3$-aminonaphthalene-2,7-disulfonic acid.

ASC removal and can almost be neglected. In a two-week continuous column study conducted in our research group, p-ASC adsorption capacity on unadapted granule sludge was only around $0.12 \mathrm{mg}$ p-ASC/g VSS (Data not shown). Starting at day 151, the UASB received more $\mathrm{p}$-ASC, up to $1000 \mathrm{mg} / \mathrm{l}$ (the p-ASC loading was as high as $1988 \mathrm{mg} / \mathrm{l} / \mathrm{day})$, to evaluate the system performance under concentration shock (Fig. 4(a, b) and Table 1). Generally, a wide range of organic compounds has been reported to be toxic to various microbial groups involved in the methanogenesis process (Chen et al., 2008). According to Sponza and Demirden (2007), the specific methanogenic activity (SMA) of granular sludge was found to decrease by $46 \%$ if the sulfamerazine was increased to $90 \mathrm{mg} / \mathrm{l}$. In another previous experiment conducted by Tsuno and Kawamura (2009), almost no methane production was observed upon increasing the terephthalate concentration up to $430 \mathrm{mg} / \mathrm{l}$. In the case of aromatic sulfonates, inhibition by LAS ( $>10 \mathrm{~g} / \mathrm{kg}$ dry sludge) on anaerobic process was also observed (Garcia et al., 2005). Clearly, inhibition concentration ranges varied widely for specific toxicants. In this work, with the increase of p-ASC concentration to 400 and $1000 \mathrm{mg} / \mathrm{l}$ (Fig. 4(b)), the COD removal decreased from $74.6 \%$ to $63.7 \%$, respectively, whereas the p-ASC removal efficiency decreased to $70 \%$ and $38 \%$. However, the increase of methane production rate and the relatively low VFA concentrations suggested that inhibition of methanogens due to an increase in the pASC concentration did not occur in the system. The decrease in the p-ASC removal efficiency with increasing p-ASC concentration (Fig. 4(b, c)) was perhaps due to the lack of sufficient p-ASC degrading bacteria because of the low growth rates of these bacteria. In a previous study, it was also shown that sulfonated aromatic amine, such as 1-aminonaphthalene-4-sulfonic acid etc., did not exhibit toxicity to the anaerobic microbes even at a concentration up to $1000 \mathrm{mg} / \mathrm{l}$ (Tan et al., 2005). The presence of an ionizable sulfonate group will result in the sulfonated aromatic amines highly soluble. Therefore, bacteria are not easily taken up by these compounds (Tan et al., 2005). In textile industries, sulfonated azo dyes are commonly used since they bond more strongly to the fiber and have lower toxicity than their non-sulfonated analog (Gan et al., 2011). Besides, the lower hydrophobicity of aromatic amines leads to less inhibitory among $\mathrm{N}$-substituted aromatics, which are 
generally reactive toxicants (Razo-Flores et al., 1997; Chen et al., 2008). Chen (2006) combined chemostat pulse technique (CPT) and a dose-response analysis to quantitatively determine the toxicity ranking of model aromatic amines (MAAs) to Pseudomonas luteola. The result suggested the relative toxicity series of MAAs were ortho $>$ meta $>$ MAA-free control $>$ para position (for isomeric aminophenols) through the CPT at $200 \mathrm{mg} / \mathrm{l}$ MAAs. Based on the molecular formula of p-ASC (Fig. 1), it can be speculated that p-ASC has lower toxicity.

\section{Treatment of p-ASC-containing wastewater without ethanol}

Usually, organic solvents (such as methanol or ethanol, etc.) are employed in large quantities in the pharmaceutical industry. Ethanol, used as a co-substrate in this study, was almost completely degraded throughout the experiment (data not shown). Shortchain alcohols, such as ethanol, can be easily degraded under both aerobic and anaerobic conditions by microbial enzymes associated with central microbial metabolic pathways (Hunt et al., 1997a). In the process of anaerobic digestion of wastewater containing complex organics, the co-substrates are often fundamental for microbial community adaptation and for the maintenance of a diverse microbial community (Okada et al., 2013).

As shown in (Fig. 4(c)), the removal efficiency of p-ASC actually increased from $68.4 \%$ to $77.4 \%$ when ethanol was removed from the synthetic wastewater, showing that p-ASC could be utilized as the sole carbon and energy source. This result was in accordance with the finding of a previous study (Sanz et al., 2003) showing that the withdrawal of co-substrates resulted in an increase in the degradation efficiency of LAS from $64 \%$ to $85 \%$ in an UASB reactor.

\section{Microbial composition analysis}

An archaeal clone library and a bacterial one were constructed using the sludge sample taken before the end of the experiment (day 190), respectively. Of 100 clones (12 OTUs), the archaeal community could be divided into seven kinds of phylogenetic groups (Table 3). The aceticlastic methanogens including the genus Methanosaeta (6 OTUs) and uncultured archaeon (2 OTUs) were dominant, accounting for $52 \%$ and $32 \%$ of total clones, respectively. The founding was in accordance with the fact that acetate was the dominant VFA during the whole experimental period (de Lucena et al., 2011). Three OTUs (36.0\% of total clones) were clustered in "Unknown Methanosaeta sp." indicting that the environment favored the growth of some novel aceticlastic methanogens. Two OTUs (12.0\% of total clones) were assigned to Methanosaeta harundinacea, a mesophilic specie isolated from a UASB reactor treating beer-manufacturing wastewater, and produced methane exclusively from acetate (Ma et al., 2006). The Methanosarcinaleslike group has been reported to be able to utilize wide range of $\mathrm{H}_{2}$, $\mathrm{CO}_{2}$, methanol, acetate and mono-, di-, and trimethylamines (Mah and Kuhn, 1984).

Table 3

Archaea composition of the granular sludge.

\begin{tabular}{llcc}
\hline Phylogenetic group & OTUs $^{\mathrm{a}}$ & No. of clones & Percentage (\%) \\
\hline Methanobacterium beijingens & 1 & 1 & 1 \\
Uncultured crenarchaeote & 1 & 1 & 1 \\
Methanosarcinales archaeon & 2 & 14 & 14 \\
Methanosaeta harundinacea & 2 & 12 & 12 \\
Methanosaeta concilii & 1 & 4 & 4 \\
Uncultured Methanosaeta sp. & 3 & 36 & 36 \\
Uncultured archaeon & 2 & 32 & 32
\end{tabular}

a OTUs were defined based on $97 \%$ sequence similarity (archaea) of $16 \mathrm{~S}$ rDNA clones.
Table 4

Bacteria composition of the granular sludge.

\begin{tabular}{lllcc}
\hline Phylum & Class & OTUs $^{\mathrm{a}}$ & No. of clones & Percentage (\%) \\
\hline Firmicutes & Erysipelotrichia & 1 & 2 & 2.3 \\
& Clostridia & 2 & 6 & 7.1 \\
Proteobacteria & Deltaproteobacteria & 8 & 31 & 36.5 \\
Chlorobi & Chlorobia & 1 & 1 & 1.1 \\
Chloroflexi & Anaerolineae & 1 & 8 & 9.4 \\
Acidobacteria & Holophagae & 1 & 1 & 1.1 \\
Bacteroidetes & Sphingobacteria & 1 & 14 & 16.5 \\
Thermotogae & Thermotogae & 2 & 15 & 17.7 \\
Planctomycetes & Planctomycetacia & 1 & 4 & 4.7 \\
Spirochaetes & Spirochaetes & 1 & 3 & 3.5 \\
\hline
\end{tabular}

a OTUs were defined based on $97 \%$ sequence similarity (bacteria) of $16 \mathrm{~S}$ rDNA clones.

Of total 85 bacterial clones (19 OTUs) identified (Table 4), 9 phyla were detected with Proteobacteria (8 OTUs, $36.5 \%$ of total clones) as the dominant one. As shown in Table 5, the phylum Proteobacteria was represented by one class closely related to Deltaproteobacteria, mainly composed of the Desulfovibrio genus (12.9\% of total clones) followed by Syntrophobacter $(8.2 \%$ of total clones), Desulfobacca (7.1\% of total clones), Smithella (4.7\% of total clones), Desulfovirga (2.4\% of total clones), and Syntrophus (1.2\% of total clones). In most of the sulfate-rich environments, the Deltaproteobacteria always constitute a big part of the microbial community (Lin et al., 2011). Desulfovibrio species can utilize wide range of organic substrates including lactate, pyruvate, and ethanol as electron donors for sulfate reduction and alternately utilize hydrogen as the sole energy (Odom and Peck, 1981). However, Desulfovibrio is not able to utilize aromatic compounds (Rabus et al., 1996) or acetate directly as electron donors (Kunapuli et al., 2010). Thus, in this work, Desulfovibrio mainly utilized ethanol as electron donor and converted it into acetate during sulfate reduction. Some of Desulfovirga species, such as Desulfovirga adipica, can completely oxide adipate in the presence of electron acceptors, such as sulfate, sulfite, thiosulfate and element sulfur (Tanaka et al., 2000). The presence of Syntrophobacter species (8.2\% of total clones), which could transfer propionate to acetate and $\mathrm{CO}_{2}$ in syntrophic coculture with methanogens (Chen et al., 2005), may explain the low concentration of propionate in the reactor. The abundance of Syntrophobacter in this reactor is thought to be closely related to the abundance of Desulfovibrio species since the co-culture of their growth groups is favored (Tanaka et al., 2000). Some of Smithella species, such as Smithella propionica, have been reported to have the ability to degrade aromatics (Liu et al., 1999). Similarly, Syntrophus-related species could degrade fatty acids and benzoate in syntrophic association with hydrogen-using microorganisms (Jackson et al., 1999). Thus, the presence of these Smithella and Syntrophus-related species is believed to closely associate with pASC degradation in this study.

Table 5

Genera in class Deltaproteobacteria.

\begin{tabular}{|c|c|c|c|c|c|}
\hline Phylum & Class & Genus & OTUs $^{\mathrm{a}}$ & $\begin{array}{l}\text { No. of } \\
\text { clones }\end{array}$ & $\begin{array}{l}\text { Percentage } \\
(\%)\end{array}$ \\
\hline \multirow[t]{6}{*}{ Proteobacteria } & Deltaproteobacteria & Smithella & 1 & 4 & 4.7 \\
\hline & & Syntrophus & 1 & 1 & 1.2 \\
\hline & & Syntrophobacter & 2 & 7 & 8.2 \\
\hline & & Desulfovibrio & 2 & 11 & 12.9 \\
\hline & & Desulfovirga & 1 & 2 & 2.4 \\
\hline & & Desulfobacca & 1 & 6 & 7.1 \\
\hline
\end{tabular}

a OTUs were defined based on $97 \%$ sequence similarity (bacteria) of $16 \mathrm{~S}$ rDNA clones. 
Among the remaining phyla, Phylum Thermotogae (2 OTUs, $17.7 \%$ of total clones) has been associated with benzene degradation under methanogenic conditions (Chang et al., 2005). Sphingobacterium sp. ATM strain belonging to the phylum Bacteroidetes (1 OTU, $16.5 \%$ of total clones) was found to decolorize the dye and textile wastewater (Tamboli et al., 2010). The class Clostridia within Firmicutes (3 OTUs, 9.4\% of total clones) has been reported in a previous experiment for LAS degradation under anaerobic conditions (Duarte et al., 2010). Cao et al. (2003) found that Clostridium pasteurianum strain DSM 12136 could use the sulfonate group of 4toluenesulfonate as a source of sulfur. Clostridium beijerinckii strain EV4 was also observed to desulfonate alkyl- and arylsulfonates (Chien, 2005). Therefore, the Clostridia-like clones may also be responsible for the desulfonation of p-ASC. Successful degradation requires a consortium of bacteria that act on different parts of the molecule (Mogensen et al., 2003).

\section{Conclusion}

This study demonstrated that the UASB reactor can achieve almost the complete removal of $50 \mathrm{mg} / \mathrm{l} \mathrm{p}$-ASC in the presence of ethanol as the co-substrate at an OLR of $7.0 \mathrm{~g}$ COD/l/day and HRT of 0.5 days. A concentration of up to $1000 \mathrm{mg} / \mathrm{l}$ of p-ASC did not show any inhibition to anaerobic microorganisms. Simultaneous generation of sulfate and sulfide was observed though the reactor received no sulfate in the influent.

The anaerobic degradation of p-ASC was achieved with or without ethanol. The aceticlastic uncultured Methanosaeta sp. and uncultured archaeon were the dominant methanogens. Bacterial groups within the phyla Proteobacteria and Thermotogae might be mainly responsible for the degradation of benzene ring of p-ASC. The phylum Clostridia plays the role for the desulfonation of p-ASC.

\section{Acknowledgments}

This study was supported by :1)Ministry of Science and Technology of the People's Republic of China (2012AA063401, 2013DFG50150), 2)National Natural Science Foundation of China 51178449,3 ) Japan Society for the Promotion of Science (JSPS 20122015) (CAS 11209).

\section{References}

APHA, 1998. Standard Methods for Examination of Water and Wastewater, 20th ed. American Public Association, New York.

Brás, R. Gomes, A., Ferra, M.I.A., Pinheiro, H.M., Goncalves, I.C., 2005. Monoazo and diazo dye decolourisation studies in a methanogenic UASB reactor. J. Biotechnol. $115,57-66$.

Cao, X., Liu, X., Dong, X., 2003. Alkaliphilus crotonatoxidans sp. nov., a strictly anaerobic, crotonate-dismutating bacterium isolated from a methanogenic environment. Int. J. Syst. Evol. Microbiol. 53, 971-975.

Carvalho, M.C., Pereira, C., Gonc-alves, I.C., Pinheriro, H.M., Santos, A.R., Lopes, A. Ferra, M.I., 2008. Assessment of the biodegradability of a monosulfonated azo dye and aromatic amines. Int. Biodeterior. Biodegradation 62, 96-103.

Chang, W., Um, Y.S., Pulliam Holoman, T.R., 2005. Molecular characterization of anaerobic microbial communities from benzene-degrading sediments under methanogenic conditions. Biotechnol. Prog. 21, 1789-1794.

Chelliapan, S., Wilby, T., Yuzir, A., Sallis, P.J., 2011. Influence of organic loading on the performance and microbial community structure of an anaerobic stage reactor treating pharmaceutical wastewater. Desalination 271, 257-264.

Chen, B.Y., 2006. Toxicity assessment of aromatic amines to Pseudomonas luteola: chemostat pulse technique and dose-response analysis. Process Biochem. 41, 1529-1538.

Chen, S.Y., Liu, X.L., Dong, X., 2005. Syntrophobacter sulfatireducens sp. nov., a nove syntrophic, propionate-oxidizing bacterium isolated from UASB reactors. Int. J. Syst. Evol. Microbiol. 55, 1319-1324.

Chen, Y., Cheng, J.J., Creamer, K.S., 2008. Inhibition of anaerobic digestion process: a review. Bioresour. Technol. 99, 4044-4064.

Chien, C.C., 2005. Arylsulfonates as sole source of sulfur for Clostridium pasteurianum DSM 12136. J. Basic Microbiol. 45, 274-278. de Lucena, R.M., Gavazza, S., Florencio, L., Kato, M.T., de Morais, M.A., 2011. Study of the microbial diversity in a full-scale UASB reactor treating domestic wastewater. World J. Microbiol. Biotechnol. 27, 2893-2902.

de Oliveira, L.L., Costa, R.B., Okada, D.Y., Vich, D.V., Duarte, I.C.S., Silva, E.L., Varesche, M.B.A., 2010. Anaerobic degradation of linear alkylbenzene sulfonate (LAS) in fluidized bed reactor by microbial consortia in different support materials. Bioresour. Technol. 101, 5112-5122.

Denger, K., Kertesz, M.A., Vock, E.H., Schon, R., Magli, A., Cook, A.M., 1996. Anaerobic desulfonation of 4-tolylsulfonate and 2-(4-sulfophenyl) butyrate by a Clostridium sp. Appl. Environ. Microbiol. 62, 1526-1530.

Duarte, I.C.S., Oloveira, L.L., Saavedra, N.K., Fantinatti-Garboggini, F., Menezes, C.B.A., Oliveira, V.M., Varesche, M.B.A., 2010. Treatment of linear alkylbenzene sulfonate in a horizontal anaerobic immobilized biomass reactor. Bioresour. Technol. $101,606-612$.

Gan, H.M., Shahir, S., Ibrahim, Z., Yahya, A., 2011. Biodegradation of 4aminobenzenesulfonate by Ralstonia sp. PBA and Hydrogenophaga sp. PBC isolated from textile wastewater treatment plant. Chemosphere 82. 507-513.

Garcia, M.T., Gampos, E., Ribisa, I., Latorre, A., Sanchez-Leal, J., 2005. Anaerobic digestion of linear alkylbenzene sulfonates: biodegradation kinetics and metabolite analysis. Chemosphere 60, 1636-1643.

Hazrati, H., Shayegan, J., 2011. Optimizing OLR and HRT in a UASB reactor for pretreating high-strength municipal wastewater. Chem. Eng. Commun. 24, 1285-1290.

Hunt, C., Alvarez, P., dos Santos Ferreira, R., Corseuil, H., 1997a. Effect of ethanol on aerobic BTEX degradation. In: Alleman, B.C., Leeson, A.L. (Eds.), In Situ and Onsite Bioremediation. Battelle Press, Columbus, OH, pp. 49-54.

Jackson, B.E., Bhupathiraju, V.K., Tanner, R.S., Woese, C.R., McInerney, M.J., 1999. Syntrophus aciditrophicus sp. nov., a new anaerobic bacterium that degrades fatty acids and benzoate in syntrophic association with hydrogen-using microorganisms. Arch. Microbiol. 171, 107-114.

Kunapuli, U., Jahn, M.K., Lueders, T., Geyer, R., Heipieper, H.J., Meckenstock, R.U., 2010. Desulfitobacterium aromaticivorans sp. nov. and Geobacter toluenoxydans sp. nov., iron-reducing bacteria capable of anaerobic degradation of monoaromatic hydrocarbons. Int. J. Syst. Evol. Microbiol. 60, 686-695.

Lange, F.T., Wenz, M., Brauch, H.J., 1995b. Race-level determination of aromatic sulfonates in water by on-line ion-pair extraction/ion-pair chromatography and their behavior in the aquatic environment. J. High Resolut. Chromatogr. 18, $243-252$.

Lin, W.T., Luo, J.F., Guo, Y., 2011. Comparison and characterization of microbial communities in sulfide-rich wastewater with and without propidium monoazide treatment. Curr. Microbiol. 62, 374-381.

Liu, Y., Balkwill, D.L., Aldrich, H.C., Drake, G.R., Boone, D.R., 1999. Characterization of the anaerobic propionate-degrading syntrophs Smithella propionica gen. nov., sp. nov. and Syntrophobacter wolinii. Int. J. Syst. Bacteriol. 49, 545-556.

Ma, K., Liu, X.L., Dong, X.Z., 2006. Methanosaeta harundinacea sp. nov., a novel acetate-scavenging methanogen isolated from a UASB reactor. Int. J. Syst. Evol. Microbiol. 56, 127-131.

Mah, R.A., Kuhn, D.A., 1984. Transfer of the type species of the genus Methanococcus to the genus Methanosarcina, naming it Methanosarcina mazei (Barker 1936) comb. nov. et emend. and conservation of the genus Methanococcus (Approved Lists 1980) with Methanococcus vannielii (Approved Lists 1980) as the type species. Int. J. Syst. Bacteriol. 34, 263-265.

Mogensen, A.S., Haagensen, F., Ahring, B.K., 2003. Anaerobic degradation of linear alkylbenzene sulfonate. Environ. Toxicol. Chem. 22, 706-711.

Odom, J.M., Peck Jr., H.D., 1981. Hydrogen cycling as a general mechanism for energy coupling in the sulfate-reducing bacteria. Desulfovibrio sp. FEMS Microbiol. Lett. $12,47-50$.

Okada, D.Y., Delforno, T.P., Estenves, A.S., Sakamoto, I.K., Duarte, I.C.S. Varesche, M.B.A., 2013. Optimization of linear alkylbenzene sulfonate (LAS) degradation in UASB reactors by varying bioavailability of LAS, hydraulic retention time and specific organic load rate. Bioresour. Technol. 128, 125-133.

Prats, D., Ruiz, F., Vazauez, B., Rodriguez-Pastor, M., 1997. Removal of anionic and nonionic surfactants in a wastewater treatment plant with anaerobic digestion. A comparative study. Water Res. 31, 1925-1930.

Rabus, R., Fukui, M., Wilkes, H., Widdel, F., 1996. Degradative capacities and 16S rRNA-targeted whole-cell hybridization of sulfate-reducing bacteria in an anaerobic enrichment culture utilizing alkylbenzenes from crude oil. Appl. Environ. Microbiol. 62, 3605-3613.

Razo-Flores, E., Donlon, B., Field, J.A., Lettinga, G., 1996. Biodegradability of Nsubstituted aromatics and alkylphenols under methanogenic conditions using granular sludge. Water Sci. Technol. 33, 47-57.

Razo-Flores, E., Donlon, B., Lettinga, G., Field, J.A., 1997. Biotransformation and biodegradation of $\mathrm{N}$-substituted aromatics in methanogenic granular sludge. FEMS Microbiol. Rev. 20, 525-538.

Sanz, J.L., Culubret, E., de Ferrer, J., Moreno, A., Berna, J.L., 2003. Anaerobic biodegradation of linear alkylbenzene sulfonate (LAS) in upflow anaerobic sludge blanket (UASB) reactors. Biodegradation 14, 57-64.

Schloss, P.D., Handelsman, J., 2005. Introducing DOTUR, a computer program for defining operational taxonomic units and estimating species richness. Appl. Environ. Microbiol. 71, 1501-1506.

Schnell, S., Schink, B., 1991. Anaerobic aniline degradation via reductive deamination of 4-aminobenzoyl-CoA in Desulfobacterium anilini. Arch. Microbiol. 155, 183-190. 
Sponza, D.T., Demirden, P., 2007. Treatment of sulfamerazine in sequential upflow anaerobic sludge blanket reactor (UASB)/completely stirred tank reactor (CSTR) processes. Sep. Sci. Technol. 56, 108-117.

Su, Y.X., Yang, J.Q., 2002. Improved technology for synthesis of p-acetanmidobenzenesulfonyl chloride. J. Hebei Norm. Univ., Nat. Sci. Ed. 26, 162-164.

Sun, D.Y., Guan, X.Y., 2009. Elimination of interference on COD measurement by $\mathrm{K}_{2} \mathrm{Cr}_{2} \mathrm{O}_{7}$ method. Environ. Sci. Manag. 34, 124-126 (in Chinese).

Tamboli, D.P., Kagalkar, A.N., Jadhav, M.U., Jadhav, J.P., Govindwar, S.P., 2010. Production of polyhydroxyhexadecanoic acid by using waste biomass of Sphingobacterium sp. ATM generated after degradation of textile dye Direct Red 5B. Bioresour. Technol. 101, 2421-2427.

Tan, N.C.G., van Leeuwen, A., van Voorthuizen, E.M., Slenders, P., PrenafetaBoldú, F.X., Temmink, H., Lettinga, G., Field, J.A., 2005. Fate and biodegradability of sulfonated aromatic amines. Biodegradation 16, 527-537.
Tan, S., Yang, Y., Luo, Z.P., Zhao, S., Huang, D.F., Zhang, J., Dong, L.C., Wang, G., 2011 An alternative synthetic process of p-acetaminobenzenesulfonyl chloride through combined $\mathrm{HClSO}_{3}$ and $\mathrm{PCl}_{5}$. Chem. Pap. 65, 510-518.

Tanaka, K., Stackebrandt, E., Tohyama, S., Eguchi, T., 2000. Desulfovirga adipica gen. nov., sp. nov., an adipate-degrading, gram negative, sulfate reducing bacterium. Int. J. Syst. Bacteriol. 50, 639-644.

Tsuno, H., Kawamura, M., 2009. Development of an expanded-bed GAC reactor for anaerobic treatment of terephthalate-containing wastewater. Water Res. 43, 417-422.

Zerbinati, O., Vincenti, M., Pittavino, S., Gennaro, M.C., 1997. Fate of aromatic sulfonates in fluvial environment. Chemosphere 35, 2295-2305. 